\title{
The Necessity of Applying Accrual Accounting in Establishing Performance Budgeting System (An Analytical Study)
}

\author{
Soleimani Hojjat \\ Department of Management, Economics and Accounting, Payame Noor University. \\ I.R. of Iran
}

Soleimani Hamid (Corresponding Author)

Department of Management, Economics and Accounting, Payame Noor University.

I.R. of Iran

Tell: 00-98-935-361-2723_Ｅmail: hsoleymani54@yahoo.com

\section{Vaghfi Seyed Hesam}

Department of Management, Economics and Accounting, Payame Noor University.

I.R. of Iran

Salehfar Davood

Department of Management, Economics and Accounting, Payame Noor University.

I.R. of Iran

Received: October 04, 2012 Accepted: October 24, 2012 DOI: 10.5296/ijafr.v2i2.2496

\begin{abstract}
Nowadays, governments have considered the novel management approaches, namely modifying their budgeting systems into performance-based ones due to the increasing pressure to enhance responsiveness and performance transparency. Hence, operational budgeting, as the most optimum accepted method of budgeting, has been put under the spotlight of governments. The differentiating character of this system from the traditional
\end{abstract}


systems is its focus on the objectives, consequences and calculating the actual cost of activities, reducing the costs and improving the quality of services provided for people. Planning and successful execution of operational budgeting system has a strong correlation with the characteristics of the governmental accounting system and financial reporting. An important prerequisite for reconciliation of the budgeting system is to modify the accounting system, so that it could calculate the actual price. Development and implementation of the operational budgeting in the governmental agencies requires application of accrual accounting in order to determine the actual costs of programs and activities. In this research, operational budgeting and accrual accounting were addressed with an analytical approach and the necessity of establishing accrual accounting, as a prerequisite for implementation of the budgeting on an operational basis was emphasized.

Keywords: Performance Budgeting, Accrual Accounting, Budget Reform

\section{Introduction}

By extending the responsibilities of government and rapid increase in governmental costs and its linkage with the general state of the country's economy, the expenses control has lost its importance and the need for enhancing the planning, control and public sector's resources management systems, the necessity of the objectives' determination and emphasize on the results to reduce costs and improving the quality of services, have been appeared. The emphasize on the results and consequences leads to a more comprehensive vision of users and their more extensive information about the results of the performance and the costs of activities' implementations. This issue draws attention of statesmen and policymakers to economic status, efficiency and effectiveness of the governmental resources. Dealing with these conditions, not only has created the need for enhancement of the methods and procedures of budgeting, but also has proposed a new dimension in revision and evaluation of the management of the governmental activities. In response to these changes, many countries have transformed their accounting and public sector budgeting systems and have considered the implementation of operational budgeting and accrual accounting.

\section{The importance of financial reporting system in governments and public sector institutions}

The tendency to financial reporting has been increased by globalization of financial resources management improvement issues and responsiveness in this sector. The existence of a transparent and efficient financial reporting system has been always of importance for governments due to the raise in people awareness of the usage of public resources. By understanding the importance of financial reporting system, the developing countries also have initiated implementation of an accounting system based on accrual accounting in public sector. An efficient financial reporting system could be advantageous in increasing the reliability of financial information, public confidence and foreign investment attraction. Some of the reasons for importance of a financial reporting system are as follow (SAFA, 2006):

- An appropriate financial reporting system is necessary in using the public resources;

- The financial reporting system motivates investors through the transparency in 


\section{Ml Macrothink}

International Journal of Accounting and Financial Reporting

ISSN 2162-3082

2012, Vol. 2, No. 2

decision-making, proper supervision, comparability of financial reporting with the other countries and financial information reliability;

- A financial reporting system based on international standards is advantageous in fundraising from international markets;

- The taxpayers should be aware of the quality of spending the government tax proceeds and the financial reporting responds this need;

- International credit agencies want to know that if the government is able to realize its commitments in the maturity date. The reporting system facilitates the reliability of crediting process.

Therefore, given the fact that the basis of deliberate accounting on the extracted information from financial reporting system is effective in public sector, it is necessary to choose a correct basis, so that the prepared financial statements based on it, meet the users' needs in the best possible manner.

\section{Types of basis in accounting}

Cash basis is an accounting method based on cash receipts and expenditures. In this method, any change in financial status of the institution requires cash exchange; incomes are identified and recorded when their cash were received and costs are identified and recorded when their cash were paid. This method was being used by government worldwide due to the feasibility of gathering the accounting information on cash basis. In this basis, the government's budgets and allocations are on the cash basis and it is easier to control the receipts and expenditures. Understanding and explanation of the principles and information gathering on the cash basis are easier and operational costs are less.

The accounting system on the cash basis, however, has some constraints and deficiencies, namely the debts and assets data being not available, solely focusing on the cash flows in current period, incompatibility of costs and incomes, some difficulties in understanding the receipts and expenditures reporting data in detail and above all of these, the government responsiveness about using public resources not being realized (SAFA, 2006).

Changing from cash basis accounting into accrual accounting is not only a change in the accounting system, but also a conceptual change in applying accounting principles and standards in public sector management.

The following advantages would be yielded by implementing accrual accounting:

- Accrual accounting is necessary in determination of the actual price and costs of the governmental organizations' programs, operations and activities within the approved credits;

- Precise control of incomes and the other funding resources, costs and all other payments of independent accounts would be feasible if accrual accounting is used;

- The accrual basis, provides more complete and more comprehensive information for legislature, government and the other authorities and the country's people in order to monitoring the performance of governmental organizations and its evaluation; 
- Accrual accounting provides the governmental organizations' managers with more accurate and more correct financial reporting in order to planning, decision-making and execution of programs' operations.

Organization for Economic Cooperation and Development, conducted a study about using accrual accounting in public sector in 1993 and mentioned that using this basis in public sector may cause reflection and introduction of a basis for responsiveness of public sector managers, facilitating more effective and efficient management of resources, enhancing responsiveness via developing the performance-based thinking and generating more focus on government influence and managerial decisions (McPhee, 2006).

South Asian Federation of Accountants states that using the accrual basis causes improvement in the quality of governments' financial reporting and accessibility of more comparable financial information. The value of debts and assets is determined by more reliability and adoption of costs with income is done better. The reliability of financial information increases and above all of these, the performance evaluation and responsiveness is performed better and in light of presence of an efficient financial reporting system, decision-making is far better (SAFA,2006).

One of the critics' objections about implementation of accrual accounting is that in order to utilizing the accrual accounting concepts, state agencies should act like the other commercial institutions (profit organizations). The other critique is that in accepted-by-government systems of accrual accounting, the nature of measurement is distorted, especially in areas in which there is problem regarding this measurement. While its advocates believe that using accrual basis in public sector and via increase in functionality, effectiveness, responsiveness and correct calculation of the actual cost of programs and proposed services by government, there would be the possibility to adopt accounting systems with environment (Barrett, 2004).

Thus, given the relative drawbacks of accrual accounting and its more advantages relative to cash basis, its implementation in public sector seems to be necessary. In this method, some of the financial reporting needs of public sector are similar to private sector, though they could not be fully compatible due to the environmental differences. Different countries' experience in turning to accrual accounting strengthens this impression that applying this system in public sector helps the government in attaining its main objective which is trying to enhance material and spiritual welfare of whole citizens through enhancing the functionality in resources consumption.

In spite of this, there are numerous problems in executing this program, which one should provide the background for its correct implementation by seeking for the proper solutions.

\section{Strategies for solving operational issues of accrual accounting}

It is unlikely that introduction of accrual accounting, especially in developing countries, does not face with some problems. So, one should consider the mistakes and problems of those countries which are using accrual accounting. For example, Australian National Audit Office annual report in 1994 and Public Accounts Joint Committee report in 1995 may be taken into account. The first problem that should be noticed - as most of countries in transition to accrual accounting noticed - is the shortage of professional accountants in different levels in 
governmental agencies. The solution for this problem in developing countries and particularly in Iran is somewhat difficult due to low expertise in state sector and lack of fast training possibility for requested people. Therefore, the government should provide possibility for training state sector's accountants prior to introducing accrual accounting. This training should also include managers who are to use accrual accounting information.

In addition, computerized training programs should be organized so that they cause increase in computer knowledge level in government (SAFA, 2006).

Changing from cash basis accounting into accrual accounting in all levels of government is a very great task, so based on experiences of some countries like Australia and New Zealand (First in local government level, then in states level and eventually in central government level), it is recommended that this task is performed in some stages, first in small governmental organizations level and if successful in whole government level (SAFA, 2006).

The culture is defined as one of affecting factors on individuals' behavior. The mutual effect of these factors during the time, gave some persistent characteristics to some groups of people that differentiated them from the others. The researches supported the important role of cultural factors in developing a legal framework of accounting procedures. Hence, it seems that the responsiveness and answer-seeking cultures have important roles in acceptance and applying accrual accounting in state sector (Hepworth, 2003).

\section{Operational budgeting}

Operational budgeting seeks for linking executive performance and resources allocation. Although these links are often weak, but information about implementation of performance increase have got better (The World Bank, 2003).

The operational budget is the budget that set up based on responsibilities, operations and projects that governmental organizations are responsible for. In Setting the operational budget, instead of considering goods and services bought by government or in the other words, instead of considering the means of activities execution, their expenditures are being considered.

The main objectives of operational budgeting are increase in efficiency of resources allocation and gain in governmental costs. Given the importance of efficiency in resources allocation, some amendments were exerted on operational budgeting in which the resources allocation tends to be responsible of the needs and social priorities. The reason for this issue is that the resources allocation for non-helpful programs is due to lack of responsibility regarding the results relating to budgeting.

The effective efficiency and efficiency in governmental resources allocation are the main objectives of operational budgeting. There is an important relation between operational budgeting and government great objectives. Clearly, the excessive expenses of government should be less than the existing value in the same amount that operational budgeting is effective in efficiency increase. In the other words, there is an effective profit that could be used to either reduce the tax load and new priorities in financial services are generated. In addition, in the case of a government which deliberately seeks for reduction in governmental 


\section{Mll Macrothink}

International Journal of Accounting and Financial Reporting

ISSN 2162-3082

2012, Vol. 2, No. 2

cost and efficiency objectives in resources allocation, its goal is to reduce the government cost and increase efficiency and effectiveness (Lauren, 2005).

\section{Accrual accounting and operational budgeting}

Development and implementation of the operational budgeting in the governmental agencies requires application of accrual accounting in order to determine the actual costs of programs and activities. In operational budgeting, in addition to the separation of credits into tasks, programs, activities and plans, the activities size and their execution costs for government and concerned agencies are calculated and determined based on actual price accounting methods which strengthens the need for accrual accounting.

The underlying rationale for these changes is that the traditional accounting system has small focus on realizing spending and responsibility against cash flows and residuals. Performance evaluation plan includes "outputs", "effectiveness" and "results" of activities and by surveying the long-term commitments and the whole financial status, takes managers as responsible for "complete costing". Accrual data are maintained to precise assessment of complete costing, services and effectiveness index of planned performance. This argument has a specific importance for the advocates of these amendments according which accrual accounting provides a more precise vision of government services. It is said that using cash basis accounting, the government is able to provide cheaper services relative to private sector, because it removes non-cash expenses such as depreciation. Thus this fact is being neglected that difference between accounting numbers on cash or accrual basis is just time. Therefore, during a long time one could not expect logically that an aggregated difference exists between reported costs by these two bases.

\section{Conclusion}

Nowadays, governments have considered the novel management approaches, namely modifying their budgeting systems into performance-based ones due to the increasing pressure to enhance responsiveness and performance transparency. Hence, operational budgeting, as the most optimum accepted method of budgeting, has been put under the spotlight of governments. The differentiating character of this system from the traditional systems is its focus on the objectives, consequences and calculating the actual cost of activities, reducing the costs and improving the quality of services provided for people. Planning and successful execution of operational budgeting system has a strong correlation with the characteristics of the governmental accounting system and financial reporting. The governmental accounting methods, which are used in traditional methods framework, are often based on cash operations. In such these methods, the main focus is on compatibility between expenditures and cashes paid or being paid (i.e. at the last phase of budget expenditure). This method is not sufficient for playing managerial roles by budgeting managers in executive agencies. An important prerequisite for reconciliation of the budgeting system is to modify the accounting system, so that it could calculate the actual price. In cash basis method one can obtain the amount of wage or the previous month travelling cost, but the possibility to extract the cost of a planned objective or strategy is too low. In addition, adequate information about government financial activities could not be 


\section{Macrothink}

International Journal of Accounting and Financial Reporting

ISSN 2162-3082

2012, Vol. 2, No. 2

driven. As a result, decision-makings would not be performed based on up-to-date and correct information. Normally, substitution of accrual accounting would eliminate these drawbacks. Therefore, establishment of accrual accounting is introduced as one of the most important prerequisite in establishing operational budgeting.

\section{References}

- Aiken, M., Capitanio, C., Accrual Accounting Valuation and Accountability in Government: A Potentially Union, Australian Journal of Public Administration, 1995

- Barrett Pat, Financial Management in the Public Sector-How Accrual Accounting and Budgeting Enhances Governance and Accountability, August, 2004

- Barret, P., Managing in an Accrual Accounting Environment, Paper Presented to RIPA Conference (Conberra, 26 February), 1993

- Conn, N., Reservation about Governments Producing Balance Sheets, Australian Journal of Public Administration, 1996

- Guthrie, J., Application of Accrual in the Australian Sector-rhectoric or Reality, Financial Accountability and Management, 1998

- Lewis, N., AAS 29: A Critique, in Readings in Accounting Developments in the Public Sector, 1993-94, 95

- Ma, R., Mathews, R., Financial Reporting by Government Departments: ED55 - a Dissenting View, Australian Journal of Corporate Law, 1993

- Ma, R., Mathews, R., What's Wrong with ED55, Financial Forum, 1992 McCrae, M., Aiken, M., AAS 29 and Public Sector Reporting: Unresolved Issues, Australian Accounting Review,

- McPhee Ian, Financial Management in the Public Sector-How Accrual Accounting Enhances Governance and Accountability, August, 2006

- South Asian Federation of Accountants (SAFA), A Study on Accrual-Based Accounting for Government and PSEs in SAARC Countries, September, 2006 